\title{
Seasonal and Temperature Dependent Variations in Proximate Parameters and Mineral Elements of Smoke-Dried Catfish (Clarias gariepinus, Burchell, 1822) using Traditional and Eco-Friendly Kilns in Lagos, Nigeria
}

\author{
OGUNBAMBO, M M \\ Fisheries Research Unit, Department of Marine Sciences, Faculty of Science, University of Lagos, Akoka, Lagos State, Nigeria \\ *AuthorEmail:mmogunbambo@gmail.com; mogunbambo@unilag.edu.ng
}

\begin{abstract}
Smoke-drying Clarias gariepinus (catfish) provides animal protein and a source of livelihood in Lagos, Nigeria. Changes occurring to seasonal and mineral compositions of smoke-dried catfish using local Traditional Drum Kiln (TDK) and a newly constructed Eco-Friendly Kiln (EFK) fitted with a flame, drying and electronic components was carried out in this study. The smoke-drying process was carried out in both wet and dry seasons and smoke-dried catfish samples stored at ambient and adjusted refrigerated temperatures of 28 and $4{ }^{\circ} \mathrm{C}$. The smoke-drying procedure was standardized at $60-80^{\circ} \mathrm{C}$ and kiln lasted $24 \pm 3$ hours. Moisture content results showed a significant difference when the catfish samples were smoke-dried using TDK and EFK and stored in ambient and controlled temperatures in both wet and dry seasons while crude protein, lipid, ash and crude fibre values were significantly different when stored only in dry season. Mineral elements phosphorus, sodium, copper, magnesium and iron showed a significant difference when stored at both temperatures and seasons using both kilns. Mineral elements were found to be most stable in smoke-dried catfish samples when stored at controlled temperatures. This work proved that standardizing smoke-drying process using both kilns resulted in good quality smoke-dried catfish but showed that higher biochemical values were obtained when EFK is used.
\end{abstract}

\section{DOI:https://dx.doi.org/10.4314/jasem.v24i4.15}

Copyright: Copyright (C) 2020 Ogunbambo. This is an open access article distributed under the Creative Commons Attribution License (CCL), which permits unrestricted use, distribution, and reproduction in any medium, provided the original work is properly cited.

Dates: Received: 04 February 2020; Revised: 09 March 2020; Accepted: 24 March 2020

Key words: Nigeria, Smoke-drying Kilns, Seasons, Ambient, Controlled Temperatures

Fish is an important global source of animal protein and supplies about $50 \%$ of total protein intake of the average Nigerian (Abolagba and Melle, 2008).It is generally considered to be more affordable than other animal protein sources such as eggs and meat, has high nutritive values and improves overall human health (Oriakpono et al., 2013). Harvesting, processing and marketing of fish products provide major foreign exchange for many countries including Nigeria where it employs to about 6 million people (Kareem, 2011).

Nigeria is presently one of the biggest importers of fish in Africa because of her teeming populationof about 170 million people which has a fish demand estimate of 2.1 million metric tons. The domestic fish production however can only supply about 900,000 metric tons, with the deficit mostly resolved by importation (NBS, 2013). African mudfish Clarias gariepinus (Burchell, 1822), also known as African sharp tooth catfish of the family Clariidae is presently the most successfully cultured in Nigeria because of its resilient nature, ability to thrive under stressful conditions such as low oxygen concentrations and its high feed to muscle conversion ratio (Agbede et al., 2003). It is one of the most highly valued freshwater fishes in Africa and especially in West Africa (Adekoya and Miller, 2004).

Irreversible spoilage of freshly harvested fish due to enzymatic and microbial degradation causes over $35 \%$ spoilage in Nigeria because of the challenge of epileptic power supply (Ndome et al., 2010). The most popular way of delaying this spoilage all year round is via processing by hot smoking using Traditional Drum Kiln (TDK) (Odekunle, 2004). Heat is applied to the fresh fish at $60^{\circ}$ to $120{ }^{\circ} \mathrm{C}$ and combines cooking, drying and smoke application till moisture content of $25 \%$ or less is achieved. The low moisture content in the smoke-dried fish ensures freshness for at least twenty-four hours before re-smoking can then be carried out (Olayemi et al., 2011). Challenges such as direct drying and excessive coating of the fish with smoke as well as the subjective process of the smokedrying process necessitated the construction of an Ecologically Friendly Kiln (EFK). Little information is available on the biochemical changes of smokedried catfish during wet and dry seasons and also when refrigerated at $4 \pm 2{ }^{\circ} \mathrm{C}$ as is obtainable in Nigeria due to the epileptic power supply. This study evaluated the proximate composition of basic biochemical constituents and mineral elements of catfish smoke-

*AuthorEmail:mmogunbambo@gmail.com; mogunbambo@unilag.edu.ng 
dried using both Traditional Drum Kiln (TDK) and Eco-Friendly Kiln (EFK) when the smoke-dried catfish samples were stored at ambient and refrigerated temperatures of 28 and $4{ }^{\circ} \mathrm{C}$ in both wet and dry seasons.

\section{MATERIALS AND METHODS}

Construction of Smoke-drying Kilns: Traditional Drum Kiln (TDK) used for this study had specifications as used in fishing villages in Lagos State, comprising a cylindrical metal drum with dimensions $72 \mathrm{~cm}$ height, $187 \mathrm{~cm}$ circumference and $55 \mathrm{~cm}$ diameter. Wood fuel was burned to generate heat through an aperture of diameter $36 \mathrm{~cm}$ and catfish samples were placed on a circular rack of diameter $76.5 \mathrm{~cm}$ on the open end for the smoke-drying process (Plate 1).

The built Eco-Friendly Kiln comprised three chambers, namely the flame, drying and electronic. The flame chamber was constructed with dimensions $93.1 \times 77.5 \times 85.2 \mathrm{~cm}$ using interlocking bricks coated with lagging material composed of clay, sawdust and silicon carbide in the ratio 4: $2: 0.5$. The wood fuel used for smoke-drying were arranged in it via an aperture with dimensions $29.6 \times 16.8 \mathrm{~cm}$. The drying chamber was separated from the flame chamber at the back with the use of smoke filters size $0.3 \mathrm{~cm}$, was built from a metal drum with same dimensions as TDK and was coated with same lagging material as the flame chamber. A drying rack composed of three layers with dimensions $44.3 \mathrm{X} 44.2 \mathrm{~cm}, 40$ and 49.5 $\mathrm{cm}$ diameters on third, middle and topmost levels respectively was installed in the drying chamber. The electronic components comprised of a temperature sensor built as a nub that was placed in smoke-drying catfish sample mouth. It transmitted heat message to visual light emitting diode and also an audio alarm which was silent when the smoke-drying temperature was less than $60{ }^{\circ} \mathrm{C}$ and made a beeping or blaring sound at optimum drying temperatures of $60-85{ }^{\circ} \mathrm{C}$ and above $85^{\circ} \mathrm{C}$ respectively(Ogunbambo et al., 2018) (Plate 2).

Sample Collection, Preparation and Analyses: Catfish samples were obtained live from the Aquaculture Unit of the Department of Marine Sciences, University of Lagos and were an average weight of $350 \pm 100 \mathrm{~g}$. They were stunned with a wooden club, degutted, thoroughly washed with clean pipe borne water and then bent into horse shoe shapes. The catfish samples were not seasoned with salt or any other condiment, allowed to drain and were arranged in both kilns and smoke-dried at a stretch at a temperature range of 60 $80{ }^{\circ} \mathrm{C}$ till the weight of the fish samples were almost constant. The smoke-drying process during both wet and dry seasons lasted 24 hours \pm 3 hours using both kilns.

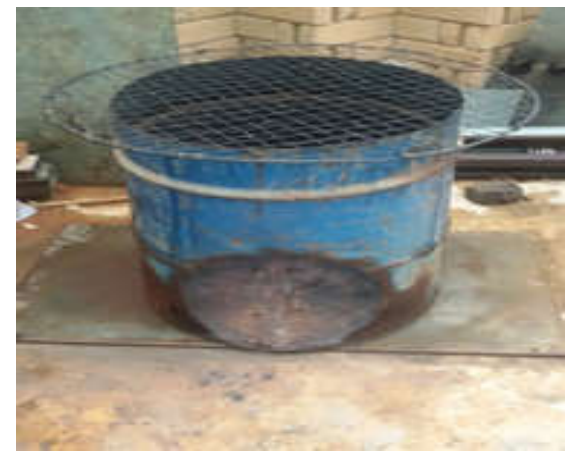

Plate 1: Constructed Traditional Drum Kiln

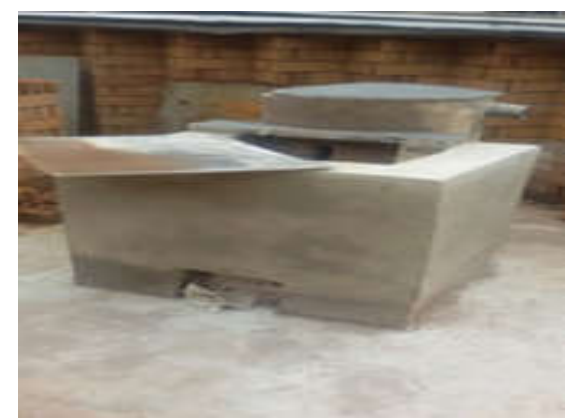

Plate 2: Constructed Eco-Friendly Kiln

The analysis of the moisture, crude protein, fat, ash and crude fiber was determined according to AOAC, 2006. The mineral elements determination as carried out by digesting the smoke-dried catfish samples in $\mathrm{HNO}_{3} / \mathrm{HCl}$. Thereafter, mineral elements Potassium $(\mathrm{K})$, Phosphorus (P), Selenium (Se), Calcium (Ca), Sodium (Na), Magnesium (Mg), Zinc (Zn), Copper $(\mathrm{Cu})$, Aluminium (Al) and Iron (Fe) were measured by a Varian Spectra Atomic Absorption Spectrophotometer (AAS), Buck Scientific 210 GVP model following procedure of Santoso et al., 2006.

Statistical Analysis: All data for the proximate analyses and mineral elements of the smoke-dried catfish were presented as means \pm standard error (SE). Analysis of variance (ANOVA) set at 0.05 level of significance, Duncan multiple-range test (DMRT) and T-test were carried out using Excel, PAST 3 and SPSS 20.0 software.

\section{RESULTS AND DISCUSSION}

Processing by smoke-drying is the most popular method of making freshly harvested fish last for longer before consumption or sales. The results of freshly harvested catfish samples smoke-dried using Traditional Drum Kiln and Eco-Friendly Kilns when stored in wet and dry season at ambient and controlled temperatures of $28^{\circ} \mathrm{C}$ are: 


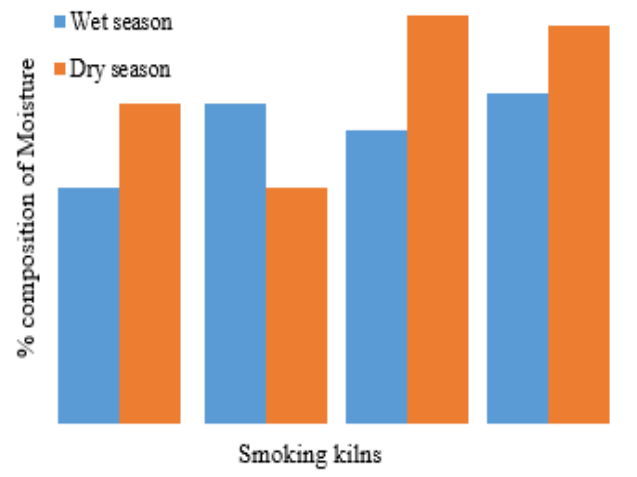

Fig 1: Percentage Composition of Moisture of Smoke-dried Catfish Stored at Ambient and Controlled Temperatures using EcoFriendly Kiln and Traditional Drum Kiln in Wet and Dry Seasons

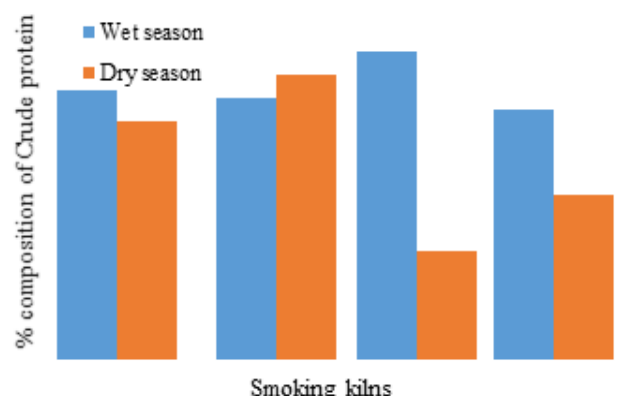

Fig 2: Percentage Composition of Crude Protein of Smoke-dried Catfish Stored at Ambient and Controlled Temperatures using EcoFriendly Kiln and Traditional Drum Kiln in Wet and Dry Seasons

Proximate Analyses: The proximate parameters of an organism, namely moisture, crude protein, lipid, ash, and crude fibre are used to ascertain the physiological condition of fish. It is considered that the higher the moisture content, the higher the rate of spoilage (Olayemi et al., 2011). The moisture content of the smoke-dried catfish samples was found to be significantly different using both Traditional Drum Kiln and Eco-Friendly Kiln in both wet and dry season. The highest value in wet season was found to be $10.72 \pm 3.01$ using TDK when stored at controlled temperature which could be because with EFK, there was proper covering and protection of the catfish samples, especially during the smoke-drying process (Figure 1). The highest and lowest moisture values in the dry season were $13.25 \pm 1.29$ and $7.69 \pm 1.05$ using EFK and TDK at controlled and ambient temperatures respectively. This can be attributed to less humidity in dry season which enabled greater moisture loss with the use of TDK. This work agreed with the works of Olayemi et al., 2011 and Ashaolu, 2014 who recommended maximum moisture levels of $12 \%$ for longer shelf life of smoke-dried fish but disagreed with the work of Egbal et al., 2013 who found a much higher moisture content when they smoke-dried Clarias lazera.

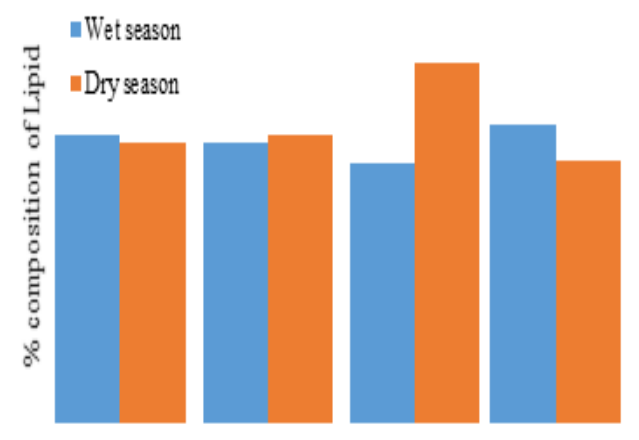

Smoking kilns

Fig 3: Percentage Composition of Lipid of Smoke-dried Catfish Stored at Ambient and Controlled Temperatures using EcoFriendly Kiln and Traditional Drum Kiln in Wet and Dry Seasons

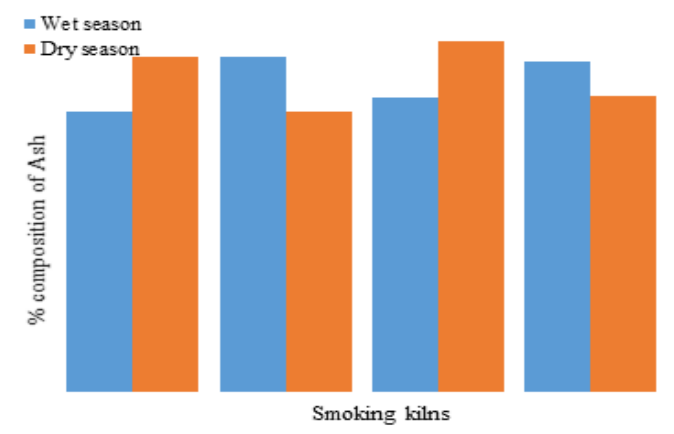

Fig 4: Percentage Composition of Ash of Smoke-dried Catfish Stored at Ambient and Controlled Temperatures using EcoFriendly Kiln and Traditional Drum Kiln in Wet and Dry Seasons

The lower moisture levels found in the smoke-dried samples using both kilns can be attributed to the standardized smoke-drying process. A significant difference was found in crude protein only in the dry season with highest and lowest values being $67.58 \pm$ 2.29 and $61.67 \pm 1.97$ using TDK at ambient temperature and EFK at controlled temperatures respectively (Figure 2). This result disagreed with the work of Egbal et al., 2013 who found much lesser protein values, thus meaning that smoke-drying fish at $60-80{ }^{\circ} \mathrm{C}$ conserves their protein content better. The lipid, ash and crude fiber contents were all found to be significantly different only in the dry season when the catfish samples were smoke-dried using TDK and EFK and then stored at ambient and controlled temperatures (Figures 3, 4 and 5). Lipid and ash contents were highest at $19.31 \pm 2.13$ and $5.63 \pm 0.72$ both using Eco-Friendly Kiln at controlled temperatures while crude fiber was highest at $3.38 \pm$ 2.06 using TDK when also stored at controlled temperature. The findings agreed with the work of Olayemi et al., 2011 with greater figures with smokedrying the catfish samples than when the catfish was fresh. 
Mineral Element Composition: Mineral elements often function in human bodies as components of enzymes which take part in metabolic activities (Shul'Man, 1974). They also contribute to the growth of fish although needed in small quantities. The most crucial mineral elements are calcium, sodium, potassium, phosphorus, iron and chlorine while elements required in trace amounts include manganese and selenium (Shul'man, 1974; Mills, 1980). The results of the mineral elements compositions of smoke-dried Catfish samples using Traditional and Eco-Friendly Kilns when stored at ambient and controlled temperatures in the wet and dry season are as shown in Table 1. Ten mineral elements were evaluated namely Potassium (K), Phosphorus (P), Selenium (Se), Calcium (Ca), Sodium $(\mathrm{Na})$, Magnesium (Mg), Zinc ( $\mathrm{Zn})$, Copper $(\mathrm{Cu})$, Aluminium (Al) and Iron (Fe) and there was no definite pattern in the distribution of the mineral elements parameters.

Table 1: Seasonal Variations in Mineral Element Compositions of Smoke-dried Clarias gariepinus using Traditional and Eco-Friendly Kilns and Stored at Ambient and Controlled Temperatures

\begin{tabular}{|c|c|c|c|c|c|}
\hline \multirow{2}{*}{\multicolumn{2}{|c|}{$\begin{array}{l}\text { Mineral } \\
\text { Elements }\end{array}$}} & \multicolumn{2}{|c|}{ Ambient Temperature } & \multicolumn{2}{|c|}{ Controlled Temperature } \\
\hline & & \multirow{2}{*}{$\frac{\text { Dry Season }}{4.24 \pm 0.04^{\mathrm{ab}}}$} & \multirow{2}{*}{$\frac{\text { Wet Season }}{4.34 \pm 0.19^{\mathrm{ab}}}$} & \multirow{2}{*}{$\frac{\text { Dry Season }}{4.02 \pm 0.03^{\mathrm{ab}}}$} & \multirow{2}{*}{$\frac{\text { Wet Season }}{4.25 \pm 0.03^{\mathrm{ab}}}$} \\
\hline & TDK & & & & \\
\hline K & EFK & $4.43 \pm 0.04^{\mathrm{ab}}$ & $4.45 \pm 0.01^{\mathrm{ab}}$ & $4.22 \pm 0.03^{\mathrm{ab}}$ & $4.29 \pm 0.03^{\mathrm{ab}}$ \\
\hline \multirow{2}{*}{$\mathbf{P}$} & TDK & $4338.95 \pm 64.73^{\mathrm{ab}}$ & $4920.46 \pm 2.25^{\mathrm{ab}}$ & $4483.05 \pm 25.58^{\mathrm{ab}}$ & $4555.22 \pm 26.45^{\mathrm{ab}}$ \\
\hline & EFK & $4416.12 \pm 68.17^{\mathrm{a}}$ & $4884.39 \pm 8.18^{\mathrm{a}}$ & $4515.02 \pm 27.11^{\mathrm{a}}$ & $4687.07 \pm 21.47^{\mathrm{a}}$ \\
\hline \multirow{2}{*}{ Se } & TDK & $0.45 \pm 0.01^{\mathrm{a}}$ & $0.54 \pm 0.01^{\mathrm{a}}$ & $0.48 \pm 0.01^{\mathrm{a}}$ & $0.52 \pm 0.01^{\mathrm{a}}$ \\
\hline & EFK & $0.46 \pm 0.01^{\mathrm{a}}$ & $0.53 \pm 0.01^{\mathrm{a}}$ & $0.49 \pm 0.01^{\mathrm{a}}$ & $0.53 \pm 0.01^{\mathrm{a}}$ \\
\hline \multirow{2}{*}{ Ca } & TDK & $0.09 \pm 0.01^{\mathrm{a}}$ & $0.11 \pm 0.01^{\mathrm{a}}$ & $0.098 \pm 0.004^{\mathrm{a}}$ & $0.10 \pm 0.005^{\mathrm{a}}$ \\
\hline & EFK & $0.09 \pm 0.01^{\mathrm{a}}$ & $0.11 \pm 0.01^{\mathrm{a}}$ & $0.11 \pm 0.005^{\mathrm{a}}$ & $0.10 \pm 0.01^{\mathrm{a}}$ \\
\hline \multirow{2}{*}{$\mathbf{N a}$} & TDK & $0.43 \pm 0.01^{\mathrm{a}}$ & $0.52 \pm 0.01^{\mathrm{a}}$ & $0.45 \pm 0.004^{\mathrm{a}}$ & $0.49 \pm 0.01^{\mathrm{a}}$ \\
\hline & EFK & $0.45 \pm 0.01^{\mathrm{a}}$ & $0.51 \pm 0.01^{\mathrm{ab}}$ & $0.45 \pm 0.01^{\mathrm{ab}}$ & $0.51 \pm 0.005^{\mathrm{a}}$ \\
\hline \multirow{2}{*}{ Mg } & TDK & $0.21 \pm 0.01^{\mathrm{a}}$ & $0.25 \pm 0.01^{\mathrm{a}}$ & $0.22 \pm 0.005^{\mathrm{a}}$ & $0.24 \pm 0.01^{\mathrm{a}}$ \\
\hline & EFK & $0.23 \pm 0.01^{\mathrm{ab}}$ & $0.25 \pm 0.01^{\mathrm{a}}$ & $0.24 \pm 0.005^{\mathrm{a}}$ & $0.24 \pm 0.01^{\mathrm{a}}$ \\
\hline \multirow{2}{*}{$\mathbf{Z n}$} & TDK & $5.77 \pm 0.05^{\mathrm{ab}}$ & $6.33 \pm 0.03^{\mathrm{ab}}$ & $5.73 \pm 0.03^{\mathrm{ab}}$ & $5.78 \pm 0.04^{\mathrm{ab}}$ \\
\hline & EFK & $5.98 \pm 0.05^{\mathrm{ab}}$ & $5.86 \pm 0.05^{\mathrm{ab}}$ & $5.91 \pm 0.03^{\mathrm{ab}}$ & $6.17 \pm 0.04^{\mathrm{ab}}$ \\
\hline \multirow{2}{*}{$\mathbf{C u}$} & TDK & $0.68 \pm 0.01^{\mathrm{a}}$ & $0.69 \pm 0.01^{\mathrm{a}}$ & $0.67 \pm 0.006^{\mathrm{a}}$ & $0.67 \pm 0.01^{\mathrm{a}}$ \\
\hline & EFK & $0.70 \pm 0.01^{\mathrm{a}}$ & $0.69 \pm 0.01^{\mathrm{ab}}$ & $0.69 \pm 0.01^{\mathrm{a}}$ & $0.67 \pm 0.01^{\mathrm{ab}}$ \\
\hline \multirow{2}{*}{ Al } & TDK & $0.00 \pm 0.00^{\mathrm{a}}$ & $0.0001 \pm 0.001^{\mathrm{a}}$ & $0.00 \pm 0.005^{\mathrm{a}}$ & $0.00 \pm 0.005^{\mathrm{a}}$ \\
\hline & EFK & $0.00 \pm 0.00^{\mathrm{a}}$ & $0.0001 \pm 0.008^{\mathrm{a}}$ & $0.00 \pm 0.005^{\mathrm{a}}$ & $0.00 \pm 0.005^{\mathrm{a}}$ \\
\hline \multirow{2}{*}{$\mathrm{Fe}$} & TDK & $3.79 \pm 0.08^{b}$ & $4.27 \pm 0.05^{\mathrm{ab}}$ & $3.90 \pm 0.03^{\mathrm{ab}}$ & $3.97 \pm 0.03^{\mathrm{ab}}$ \\
\hline & EFK & $3.91 \pm 0.09^{\mathrm{ab}}$ & $4.17 \pm 0.05^{\mathrm{ab}}$ & $4.17 \pm 0.02^{\mathrm{ab}}$ & $4.06 \pm 0.03^{\mathrm{ab}}$ \\
\hline
\end{tabular}

Mean \pm S.E (standard errors) of each Mineral Element using TDK and EFK
different $(p>0.05)$. TDK: Traditional Drum Kiln; EFK: Eco-Friendly Kiln

Five mineral elements, namely Phosphorus, Sodium, Magnesium, Copper, and Aluminum had values that were significantly different when the smoke-dried catfish samples were stored at ambient and controlled temperatures in wet and dry seasons. Potassium is a very significant body mineral and is crucial to both cellular and electrical functions. Together with sodium, potassium regulates water balance and the acid-base balance in the blood and tissues. It is also a co-factor for many enzymes and is required for insulin secretion, carbohydrate metabolism as well as protein synthesis (Kawahara, 2007). The potassium levels of smoke-dried catfish using EFK were all found to be higher than those smoke-dried using TDK when the samples were stored at ambient and controlled temperatures in wet and dry seasons and could be as a result of better conservation of nutrient by EFK. Aluminum though is the most abundant element in the earth crust, is not essential for life and its high consumption has been linked to neurodegenerative diseases such as amyotrophic lateral sclerosis and Parkinsonism-dementia because of its long half-life in the body (Kawahara, 2007). The almost zero in all the values of aluminum found in the smoke-dried catfish using TDK and EFK shows that the processed fish samples are safe for consumption. Phosphorus, Sodium, Magnesium, Copper and Iron results showed a significant difference when the smoke-dried catfish samples were stored at ambient and controlled temperatures in the wet and dry season.

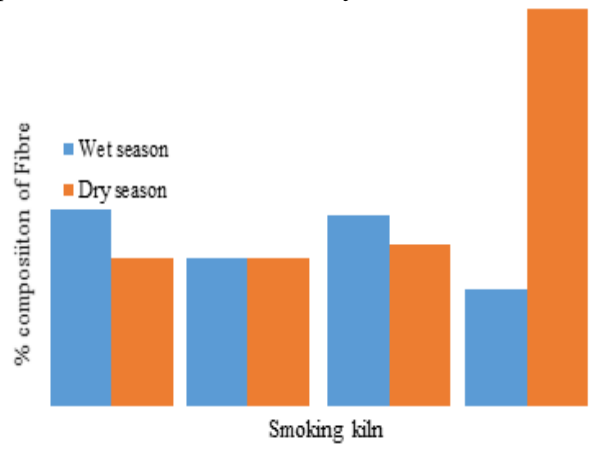

Fig 5: Percentage Composition of Fibre of Smoke-dried Catfish Stored at Ambient and Controlled Temperatures using Eco-friendly Kiln and Traditional Drum Kiln in Wet and Dry Season 
Phosphorus had highest and lowest values of 4920.46 \pm 2.25 and $4338.95 \pm 64.73$ both when smoke-dried using TDK and stored at ambient temperature but in wet and dry season respectively. Sodium had the highest and lowest values of $0.52 \pm 0.01$ and $0.42 \pm$ 0.01 both when smoke-dried using TDK and stored at ambient temperature but at wet and dry seasons respectively. Magnesium values were highest at 0.25 \pm 0.01 twice in the wet season and ambient temperature but using both TDK and EFK while lowest was found to be $0.21 \pm 0.01$ in the dry season and ambient temperature when smoke-dried using TDK. Copper had highest and lowest values of $0.70 \pm$ 0.01 and $0.67 \pm 0.006$ using TDK and EFK when both were stored in the dry season but at ambient and controlled temperatures respectively. Iron had highest and lowest values of $4.27 \pm 0.05$ and $3.79 \pm 0.08$ both at ambient temperatures, using TDK but in dry and wet season respectively.

Conclusion: The construction of Eco-Friendly Kiln with similar usage to existing Traditional Drum Kiln and the standardization of the smoke-drying process to between $60-80{ }^{\circ} \mathrm{C}$ using both kilns has shown that good quality smoke-dried fish can be produced using either kiln. Higher biochemical values in smoke-dried catfish obtained with the use of EFK however proves that it is an improvement over TDK. This work has also shown that mineral elements in smoke-dried catfish samples are more stable when stored at controlled temperatures using either kiln.

Acknowledgements: The author is grateful to Dr. Moruf Olatunji, a fisheries specialist in Bayero University Kano for his help with the design of this work and Mr. Yemi Obateru for his revision of this manuscript.

\section{REFERENCES}

Abolagba, OJ; Melle, OO (2008). Chemical Composition and Keeping Qualities of a Scaly Fish Tilapia, Oreochromis niloticus Smoked with Two Energy Sources. Afr. J. Gen. Agric. 4 (2): 11-15.

Adekoya, BB; Miller, JW (2004). An Overview National Cultures. Agric Foc. 15: 10pp.

Agbede, SA; Adeyemo, K; Adedeji, OB; Olaniyan, AO; Esuruoso, GO (2003). Small Scale Fish Production in Veterinary Practice. Nig. Vet. J. 24 (3): 172-178.

AOAC (2006). Association of Official Analytical Chemists. Official Methods of Analysis, 23rd Edition. Airlington, VA, USA. 4: 48 - 55.
Ashaolu, MO (2014). Development and Performance Evaluation of a Motorized Fish Smoking Kiln. Afr. J. Food Science Tech. 5(5):119 - 124.

Egbal, O; Mohammed, E; Regiah, A; Hana, M; Asgad, A (2013). Investigation the Quality Change of Raw and Hot Smoked Oreochromis niloticus and Clarias lazera. Pak. J. Nutr. 5:481- 484

Kawahara, A (2007). Aluminum and Human Health: Its Intake, Bioavailability and Neurotoxicity. Bio. Res. Trace Elem.18 (3): 211 - 220.

Mills, CF (1980). The Mineral Nutrition of Livestock. Underwood, E.J. (Ed.). Common Wealth Agricultural Bureaux.

National Bureau of Statistics (2013). 2012 and Estimate for Q1, 2013. Gross Domestic Production for Nigeria. National Bureau of Statistics, Abuja-Nigeria. May, 2013. p.15.

Ndome, C; Oriakpono, O; Agnes, O (2010). Proximate Composition and Nutritional Value of some Commonly Consumed Fishes in Calabar. $J$. Trop. Fr. Wat. Bio.19 (1): 81 - 93.

Odekunle, TO (2004). Rainfall and the Length of the Growing Season in Nigeria. Int. J.Clim. 24: 467 $-479 \mathrm{pp}$.

Ogunbambo, MM; Osibona, AO; Boyo, HO (2018). Comparative Drying Profiles and Polycyclic Aromatic Hydrocarbons Content of Catfish Smoke-dried using Traditional Drum and Newly Constructed Eco Fish Kiln. Unilag J. Med., Sci. and Tech. 6 (2):017 - 032.

Olayemi, FF; Adedayo, MR; Bamishaiye, EI; Awagu, EF (2011). Stored Products Research Institute (NSPRI): Developed kiln. Int. J. Fish. Aqua. 3(5): 96 - 98. (2011).

Oriakpono, O; Frank-Peterside, N; Ndome, C (2013). Microbiological assessment of stored Tilapia guineensis. Afr. J. Food Sc. 5(4): 242 - 247.

Santoso, J; Yoshie-Stark, Y; Suzuki, T (2006). Antioxidant activity of methanol extracts from Indonesian seaweeds in an oil emulsion model. Aqua. Prod. Technol. 9(1): 1 - 11.

Shul'Man, GE (1974). Life Cycle of Fish: Physiology and Biochemistry, Halsted Press a division of John Wiley and Son Inc. N.Y. (1st Ed.) 